\title{
Fatty acid and cholesterol profiles, hypocholesterolemic, atherogenic, and thrombogenic indices of broiler meat in the retail market
}

Youssef A. Attia ${ }^{1 *}$, Mohammed A. Al-Harthi ${ }^{1}$, Mohamed A. Korish ${ }^{1,3}$ and Mohamed M. Shiboob ${ }^{2}$

\begin{abstract}
Background: Broiler meat is an essential source of food due to its favourable effects on human health derived from its protein, fats, minerals, vitamins and its bioactive components.

Methods: A total of 90 carcasses were collected from the retail market in Jeddah city, Saudi Arabia during April, May and June 2014 to determine the effects of meat type (frozen vs. fresh) and sources within fresh types (A, B, C) vs. frozen types ( $D, E$ and $F$ ) on their fatty acid profiles, cholesterol, their hypocholesterolemic, atherogenic and thrombogenic indices, and on their antioxidants' status.

Results: The sources of meat had a significant effect on the hypocholesterolemic and atherogenic indices, with the D source of fresh meat having the best indices. Total saturated fatty acids (SFA), unsaturated fatty acids (UFA), the UFA/SAF ratio, and the monounsaturated (MUFA), Omega- 6 and Omega-7 fatty acids were significantly affected by the source of meat. The results revealed that the D source of fresh meat showed favourable fatty acid profiles with significant health benefits for human. Correlation analyses showed a significant negative relationship between the SFA and hypocholesterolemic indices, and significant positive relationships with the atherogenic index, the thrombotgenic index and the total antioxidant capacity. In addition, the relationship between UFA and the hypocholesterolemic index was strongly significantly positive, but was highly negative between the atherogenic and thrombotic indices. The correlations between omega- 6 and total cholesterol and the atherogenic index was moderately negative, but was moderately positive with the hypocholesterolemic index.

Conclusion: Fatty acids profiles and the hypocholesterolemic and atherogenic indices of broiler meat in the retail market in Jeddah city, Saudi Arabia during April-May-June showed significant differences, with the potential for favourable fatty acids to be boosted. Such variability indicates the needs for a feeding strategy to enhance the favourable fatty acids that may positively impact the health of the consumer, lowering the risk of hypercholesterolemia, atherosclerosis, and thrombogenesis although further studies are needed.
\end{abstract}

Keywords: Atherogenic, Fatty acids, Hypercholesterolemia, Thrombogenic, Broiler meat

\footnotetext{
* Correspondence: yaattia@kau.edu.sa

${ }^{1}$ Arid Land Agriculture Department, Faculty of Meteorology, Environment and Arid Land Agriculture, King Abdulaziz University, P.O. Box 80208, Jeddah 21589, Saudi Arabia

Full list of author information is available at the end of the article
} International License (http://creativecommons.org/licenses/by/4.0/), which permits unrestricted use, distribution, and reproduction in any medium, provided you give appropriate credit to the original author(s) and the source, provide a link to the Creative Commons license, and indicate if changes were made. The Creative Commons Public Domain Dedication waiver (http://creativecommons.org/publicdomain/zero/1.0/) applies to the data made available in this article, unless otherwise stated. 


\section{Background}

Chicken meat is one of the major animal protein supplies. It contains all the nutrients that can meet the recommended daily allowances for humans [1]. Poultry meat is an extremely complex item can be assessed from the standpoint of consumer interests and from that of the slaughter industry [2]. Chicken meat has a relatively low fat content and is a respected source of proteins, vitamins and mineral sources [3].

Consumption of foods that rich of saturated fat and cholesterol, especially from animal sources were found to be responsible for the development of coronary heart diseases [4]. Ecological studies across 16 defined populations in seven countries revealed that intake of saturated fat as a percentage of calories had strong correlation with coronary death rates [5], where each $5 \%$ increase of energy from saturated fat was associated with $17 \%$ increase in coronary heart diseases [6]. Poultry meat contains a low proportion of fat and cholesterol, where it contain around $1 \%$ fat in the leanest cuts, and $17 \%$ in cooked chicken wings with skin. Poultry fat is favorable: it includes significant amounts of monounsaturated fatty acids (only a third of total fat is made up of saturated fatty acids and, in comparison with red meat, substantial amounts of polyunsaturated fats, especially the omega- 6 or n-6 linoleic acid and arachidonic acid [7]. It may represent an important source of long-chain omega-3 or n-3 fatty acids [8]. In the California Seventh-day Adventist study, higher consumption of poultry was not associated with risk of coronary heart diseases [9]. A very large observational study carried out in the United States on a female population reported an inverse relationship between the intakes of poultry and the risk of developing coronary artery disease [10].

The chemical composition of muscles is an important quality measurement of broiler meat [11]. Nutrients profiles, such as fat/fatty acids and the hypocholesterolemic, atherogenic and thrombotic indices of poultry products, were found to be important concepts in meat consumption $[2,12-15]$. Meat quality is a complex concept that is influenced by the strain of broilers $[2,16,17]$ and by diet composition, feed types and additives [13, 18, 19]. Additional influences are rearing practices, the health of the chickens, the environmental conditions, slaughter practices, storage, handling and cooking [20-22] as well as fresh vs. frozen meat $[23,24]$.

The lipids and antioxidants of poultry product are essential components from the health and consumption perspectives for humans. This status has considerable impact on meat consumption and its health implications [25-28]. Therefore studying the variability in the profiles of its fats/fatty acid profiles, cholesterol, its hypocholesterolemic, atherogenic and thrombotic indices, and its antioxidants and in its lipid peroxidation biomarkers, such as malnodialdehyde (MDA), is essential for developing quality control and for mentoring the quality of broiler meat in the retail market and its impact on human health.

\section{Results}

Cholesterol profiles, atherogenic and thrombotic indices, and antioxidant status

Table 1 shows the effects of different meat types (frozen vs. fresh) and meat sources (A, B, C, D, E and F) on the cholesterol profiles, atherogenic and thrombotic indices, and antioxidant status of meat. Frozen meat had a numerically $(P=0.054)$ higher hypocholesterolemic index, but a significantly lower $(P=0.05)$ thrombotic index when compared to fresh meat. On the other hand, differences in the lipid profiles and antioxidant indices were not significant between the types and sources of meat, except for the hypocholesterolemic and atherogenic indices, which were significantly affected by the source of meat only. Source D of fresh meat had a significantly greater hypocholesterolemic index than the other sources, except for sources A and B of frozen meat. Also, source A of frozen meat had a significantly higher hypocholesterolemic index than sources $\mathrm{E}$ and $\mathrm{F}$ of fresh meat. In addition, sources $B$ and $C$ of frozen meat had significantly higher hypocholesterolemic indices than did source $\mathrm{E}$ of fresh meat.

Source A of frozen meat and source D of fresh meat had significantly lower atherogenic indices than the other sources, except for source B of frozen meat.

\section{Fatty acid profiles of meat}

Tables 3 and 4 show the effects of the meat types and meat sources on individual and total fatty acid profiles. There was a significant effect of meat type on individual SFA (Table 2) and total SFA (Table 3). Fresh meat showed significantly greater C8:0, C11:0, C12:0, and C16:0, and thus total SFA, than did frozen meat. There was also a significant effect of meat source on individual SFA (Table 2) and total SFA (Table 3). Source E of fresh meat had significantly greater C8:0, C11:0, C12:0 and C16:0 than did the other sources of frozen and fresh meat. A similar trend was observed for C21:0, except that the differences between sources $\mathrm{E}$ and $\mathrm{F}$ of fresh meat was insignificant. This latter group had significant greater C21:0 than its counterpart group from source D. The total SFA of fresh meat from source E was significantly greater than from that of the other sources, except for source $\mathrm{F}$ of fresh meat. The latter group, and source $\mathrm{C}$ of frozen meat, had greater total SFA than did source A of frozen meat and source D of fresh meat.

There was no significant difference in most of MUFA except for C18:1 and C22:1. The C18:1 fatty acid of frozen meat was significantly greater $(20.5 \%)$ than that of 
Table 1 Effect of meat type and different source of frozen and fresh meat in the retail market on cholesterol profiles, and hypocholesterolemic, atherogenic and thrombotic indices, different type of cholesterol and indices of antioxidant status of fresh meat

\begin{tabular}{|c|c|c|c|c|c|c|c|c|c|}
\hline Parameters & $\begin{array}{l}\text { Total } \\
\text { cholesterol, } \\
\mathrm{mg} / 100 \mathrm{~g}\end{array}$ & $\begin{array}{l}\text { Low density } \\
\text { lipoprotein, } \\
\text { mg/100 g }\end{array}$ & $\begin{array}{l}\text { High density } \\
\text { lipoprotein, } \\
\text { mg/100 g }\end{array}$ & $\begin{array}{l}\text { LDL/HDL } \\
\text { ratio }\end{array}$ & $\begin{array}{l}\text { Hypocholesterolemic } \\
\text { index }\end{array}$ & $\begin{array}{l}\text { Atherogenic } \\
\text { index }\end{array}$ & $\begin{array}{l}\text { Thrombotic } \\
\text { index }\end{array}$ & $\begin{array}{l}\text { TAC } \\
\mathrm{mmoles} / 100 \mathrm{~g} \\
\text { fresh meat }\end{array}$ & $\begin{array}{l}\text { MDA, } \\
\text { mmoles } / \mathrm{g} \\
\text { fresh meat }\end{array}$ \\
\hline \multicolumn{10}{|l|}{ Meat type } \\
\hline Frozen meat & 73.1 & 37.7 & 40.6 & 0.931 & 1.91 & 0.726 & 0.679 & 1.50 & 1.95 \\
\hline Fresh meat & 72.4 & 36.9 & 39.6 & 0.933 & 1.77 & 0.782 & 0.697 & 1.51 & 1.84 \\
\hline \multicolumn{10}{|l|}{ Source of meat } \\
\hline Frozen A & 73.2 & 37.4 & 40.8 & 0.916 & $2.01^{\mathrm{ab}}$ & $0.650^{c}$ & 0.656 & 1.54 & 1.92 \\
\hline Frozen B & 72.4 & 38.3 & 39.7 & 0.966 & $1.89^{\mathrm{abc}}$ & $0.722^{\mathrm{bc}}$ & 0.671 & 1.45 & 1.96 \\
\hline Frozen C & 73.7 & 37.4 & 41.3 & 0.908 & $1.83^{\mathrm{bc}}$ & $0.807^{\mathrm{ab}}$ & 0.709 & 1.52 & 1.95 \\
\hline Fresh D & 70.5 & 36.7 & 39.2 & 0.938 & $2.11^{\mathrm{a}}$ & $0.658^{c}$ & 0.664 & 1.32 & 1.69 \\
\hline Fresh E & 73.7 & 36.8 & 40.1 & 0.920 & $1.55^{\mathrm{d}}$ & $0.891^{\mathrm{a}}$ & 0.722 & 1.66 & 1.98 \\
\hline Fresh F & 73.1 & 37.2 & 39.4 & 0.942 & $1.66^{\mathrm{cd}}$ & $0.795^{\mathrm{ab}}$ & 0.704 & 1.54 & 1.86 \\
\hline \multicolumn{10}{|c|}{ Statistical analyses } \\
\hline RSME & 2.56 & 1.905 & 1.725 & 0.067 & 0.186 & 0.037 & 0.134 & 0.204 & 0.218 \\
\hline Meat type & 0.466 & 0.258 & 0.126 & 0.915 & 0.054 & 0.185 & 0.007 & 0.958 & 0.207 \\
\hline Source of meat & 0.302 & 0.922 & 0.594 & 0.666 & 0.0006 & 0.036 & 0.201 & 0.134 & 0.383 \\
\hline
\end{tabular}

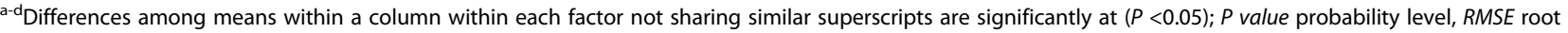
mean square error, TAC total antioxidant capacity, MDA melondialdehyde

fresh meat, but the C22:1 fatty acid was lower (41.5\%). Total MUFA was significantly greater (11.7\%) in frozen meat than in fresh meat. The differences among the different sources of meat were significant in their C18:1, 20:1 and 22:1 fatty acids. Source A of frozen meat had significantly greater C18:1 fatty acids than did the other sources, except for source B of frozen meat. Source B also showed a similar trend, except that it did not significantly differ from source $\mathrm{C}$ of frozen meat and source $\mathrm{D}$ of fresh meat. In addition, source D of fresh meat had significantly greater C20:1 than did the other sources of both types of meat except for source A of frozen meat. The latter group also exhibited C18:1 that was greater than different sources except for source B of frozen meat. Moreover, sources E and F of frozen meat showed significantly greater $\mathrm{C} 22: 1$ than did the other groups of either frozen or fresh meat. The total MUFA of source A of frozen meat was significantly greater than that of other sources. Furthermore, source B of frozen meat and sources D and $\mathrm{F}$ of fresh meat exhibited greater total MUFA than did source $E$ of fresh meat.

The only significant difference due to the source of meat was shown in C20:5 PUFA (Table 2), which indicates greater values from source $\mathrm{D}$ of fresh meat than from other sources. In addition, source $\mathrm{C}$ of frozen meat displayed a significantly greater value than did source $B$ of frozen meat and sources $\mathrm{E}$ and $\mathrm{F}$ of fresh meat. The total PUFA of fresh meat source D was significantly greater than that of other sources (Table 3).
Obviously, the PUFA/UFA ratio was significantly greater $(7.3 \%)$ in fresh meat than in frozen meat, but PUFA/MUFA (13.1\%), omega-7 (10.3\%) and omega-9 (8.8\%) fatty acids were lower (Table 3 ). The UFA and UFA/SFA ratio were significantly greater from D source of fresh meat than from the other sources, except for source A of frozen meat. The latter group also showed higher values than did the other groups, except for source B of frozen meat.

Omega-6 was also significantly greater in source D of fresh meat than in the other sources. Omega-7 in frozen meat was significantly greater from source A of frozen meat than from other sources. In addition, sources B of frozen meat and D and F of fresh meat had significantly greater omega-7 than did source $E$ of fresh meat.

\section{Correlation analyses}

Correlation analyses are displayed in (Table 4). There were significant negative relationships between SFA and UFA, MUFA, PUFA, omega-6, omega-9, omega-7 and the hypocholesterolemic index, but significant positive relationships with the atherogenic index, the thrombogenic index and total antioxidant capacity.

Correlations between UFA and MUFA, PUFA, omega-3, omega-7 were significantly positive with a moderate magnitude, while the correlation between UFA and the hypocholesterolemic index was significantly positive with a strong magnitude. In addition, the correlation between UFA and omega-9 was significant with a moderate 


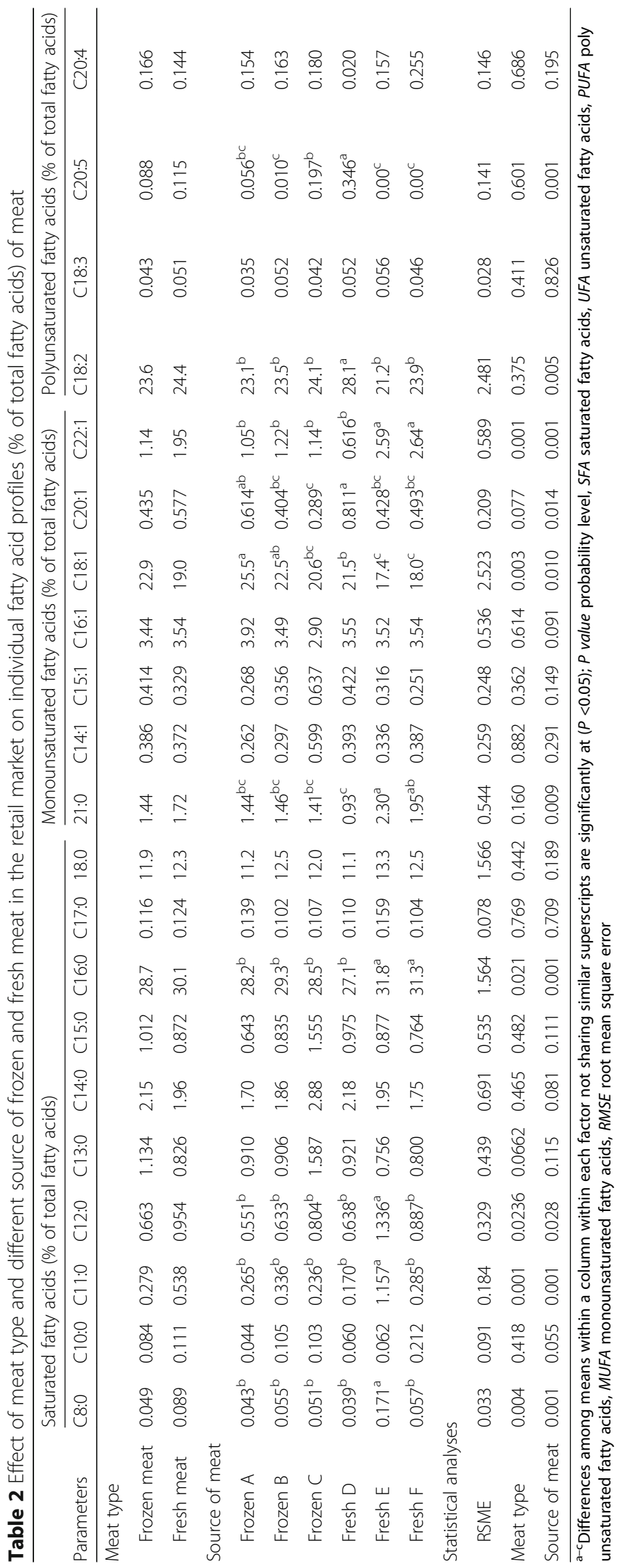




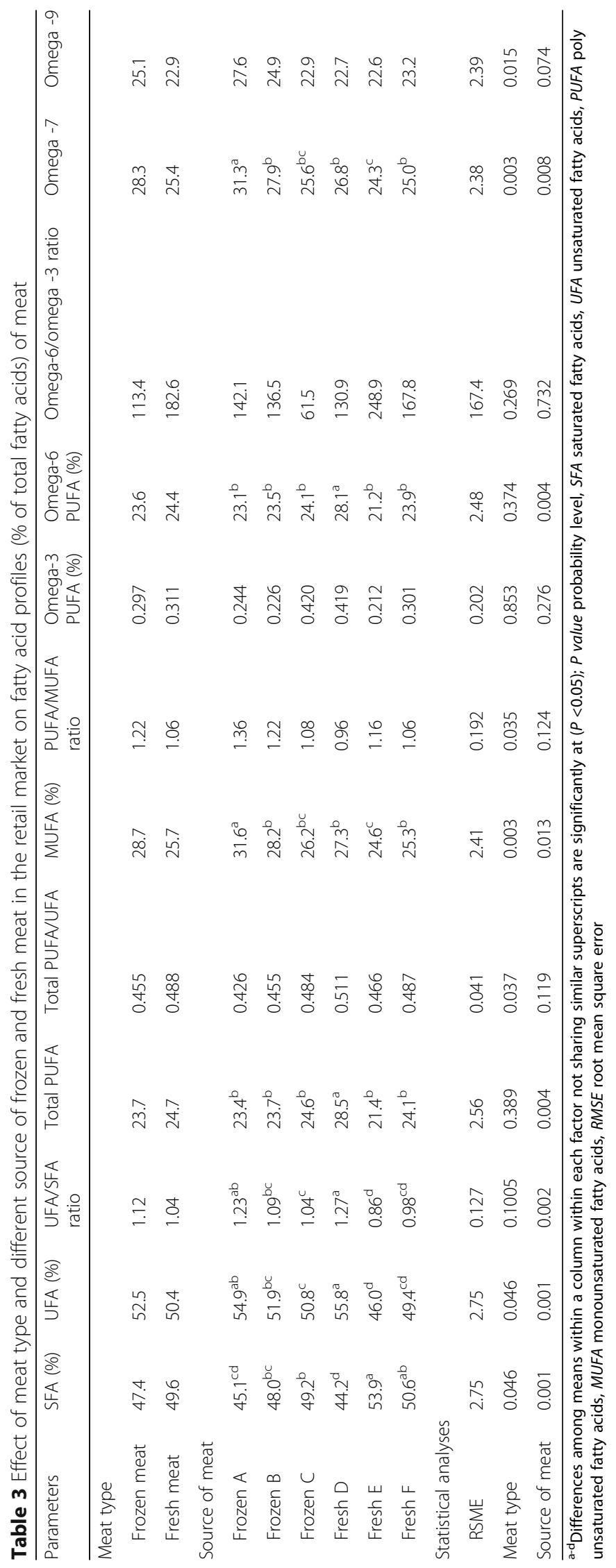


Table 4 Correlation among indices lipids profiles, antioxidant status, atherogenic and thrombotic index of chickens' meat in the retail market

\begin{tabular}{|c|c|c|c|c|c|c|c|c|c|c|c|c|c|c|c|c|}
\hline & SFA & UFA & MUFA & PUFA & Omg3 & Omg6 & Omg9 & Omg7 & Cho & LDL & $\mathrm{HDL}$ & Athl & Thrl & Hypochl & TAC & MDA \\
\hline SFA & $\begin{array}{l}1.000 \\
0.000\end{array}$ & $\begin{array}{l}-0.999 \\
0.001\end{array}$ & $\begin{array}{l}-0.647 \\
0.001\end{array}$ & $\begin{array}{l}-0.661 \\
0.001\end{array}$ & $\begin{array}{l}-0.337 \\
0.069\end{array}$ & $\begin{array}{l}-0.659 \\
0.001\end{array}$ & $\begin{array}{l}-0.453 \\
0.012\end{array}$ & $\begin{array}{l}-0.654 \\
0.001\end{array}$ & $\begin{array}{l}0.379 \\
0.039\end{array}$ & $\begin{array}{l}-0.049 \\
0.797\end{array}$ & $\begin{array}{l}0.229 \\
0.222\end{array}$ & $\begin{array}{l}0.940 \\
0.001\end{array}$ & $\begin{array}{l}0.605 \\
0.004\end{array}$ & $\begin{array}{l}-0.907 \\
0.001\end{array}$ & $\begin{array}{l}0.519 \\
0.003\end{array}$ & $\begin{array}{l}0.353 \\
0.055\end{array}$ \\
\hline UFA & & $\begin{array}{l}1.000 \\
0.000\end{array}$ & $\begin{array}{l}0.654 \\
0.001\end{array}$ & $\begin{array}{l}0.655 \\
0.001\end{array}$ & $\begin{array}{l}0.336 \\
0.069\end{array}$ & $\begin{array}{l}0.653 \\
0.001\end{array}$ & $\begin{array}{l}0.459 \\
0.011\end{array}$ & $\begin{array}{l}0.660 \\
0.001\end{array}$ & $\begin{array}{l}0-.38 \\
0.037\end{array}$ & $\begin{array}{l}0.047 \\
0.804\end{array}$ & $\begin{array}{l}-0.227 \\
0.228\end{array}$ & $\begin{array}{c}-0.94 \\
0.001\end{array}$ & $\begin{array}{l}-0.604 \\
0.004\end{array}$ & $\begin{array}{l}0.907 \\
0.001\end{array}$ & $\begin{array}{l}-0.51 \\
0.003\end{array}$ & $\begin{array}{l}-0.353 \\
0.056\end{array}$ \\
\hline MUFA & & & $\begin{array}{l}1.000 \\
0.000\end{array}$ & $\begin{array}{l}-0.143 \\
0.450\end{array}$ & $\begin{array}{l}-0.090 \\
0.635\end{array}$ & $\begin{array}{l}-0.144 \\
0.447\end{array}$ & $\begin{array}{l}0.920 \\
0.001\end{array}$ & $\begin{array}{l}0.996 \\
0.001\end{array}$ & $\begin{array}{l}0.036 \\
0.851\end{array}$ & $\begin{array}{l}0.158 \\
0.402\end{array}$ & $\begin{array}{l}0.029 \\
0.877\end{array}$ & $\begin{array}{l}-0.602 \\
0.004\end{array}$ & $\begin{array}{l}0.546 \\
0.002\end{array}$ & $\begin{array}{l}0.569 \\
0.001\end{array}$ & $\begin{array}{l}-0.004 \\
0.985\end{array}$ & $\begin{array}{l}0.078 \\
0.685\end{array}$ \\
\hline PUFA & & & & $\begin{array}{l}1.000 \\
0.000\end{array}$ & $\begin{array}{l}0.525 \\
0.002\end{array}$ & $\begin{array}{l}0.998 \\
0.001\end{array}$ & $\begin{array}{l}-0.318 \\
0.086\end{array}$ & $\begin{array}{l}-0.131 \\
0.487\end{array}$ & $\begin{array}{c}-0.53 \\
0.002\end{array}$ & $\begin{array}{l}-0.099 \\
0.603\end{array}$ & $\begin{array}{l}-0.319 \\
0.086\end{array}$ & $\begin{array}{l}-0.627 \\
0.002\end{array}$ & $\begin{array}{l}-0.248 \\
0.186\end{array}$ & $\begin{array}{l}0.616 \\
0.003\end{array}$ & $\begin{array}{l}-0.669 \\
0.001\end{array}$ & $\begin{array}{l}-0.537 \\
0.002\end{array}$ \\
\hline Omg3 & & & & & $\begin{array}{l}1.00 \\
0.000\end{array}$ & $\begin{array}{l}0.478 \\
0.008\end{array}$ & $\begin{array}{l}-0.146 \\
0.440\end{array}$ & $\begin{array}{l}-0.096 \\
0.612\end{array}$ & $\begin{array}{c}-0.20 \\
0.302\end{array}$ & $\begin{array}{l}-0.131 \\
0.489\end{array}$ & $\begin{array}{l}0.102 \\
0.958\end{array}$ & $\begin{array}{l}-0.268 \\
0.152\end{array}$ & $\begin{array}{l}0.521 \\
0.003\end{array}$ & $\begin{array}{l}0.439 \\
0.015\end{array}$ & $\begin{array}{l}-0.473 \\
0.008\end{array}$ & $\begin{array}{l}-0.239 \\
0.202\end{array}$ \\
\hline Omg6 & & & & & & $\begin{array}{l}1.000 \\
0.000\end{array}$ & $\begin{array}{l}-0.320 \\
0.084\end{array}$ & $\begin{array}{l}-0.131 \\
0.487\end{array}$ & $\begin{array}{l}-0.54 \\
0.002\end{array}$ & $\begin{array}{l}-0.093 \\
0.626\end{array}$ & $\begin{array}{l}-0.334 \\
0.071\end{array}$ & $\begin{array}{l}-0.629 \\
0.002\end{array}$ & $\begin{array}{l}-0.287 \\
0.123\end{array}$ & $\begin{array}{l}0.607 \\
0.004\end{array}$ & $\begin{array}{l}-0.663 \\
0.001\end{array}$ & $\begin{array}{l}-0.540 \\
0.002\end{array}$ \\
\hline Omg9 & & & & & & & $\begin{array}{l}1.00 \\
0.000\end{array}$ & $\begin{array}{l}0.934 \\
0.001\end{array}$ & $\begin{array}{l}0.073 \\
0.701\end{array}$ & $\begin{array}{l}0.035 \\
0.855\end{array}$ & $\begin{array}{l}0.058 \\
0.761\end{array}$ & $\begin{array}{l}-0.487 \\
0.006\end{array}$ & $\begin{array}{l}-0.401 \\
0.028\end{array}$ & $\begin{array}{l}0.372 \\
0.04\end{array}$ & $\begin{array}{l}0.086 \\
0.651\end{array}$ & $\begin{array}{l}0.103 \\
0.586\end{array}$ \\
\hline Omg7 & & & & & & & & $\begin{array}{l}1.000 \\
0.000\end{array}$ & $\begin{array}{l}0.01 \\
0.959\end{array}$ & $\begin{array}{l}0.134 \\
0.479\end{array}$ & $\begin{array}{l}0.013 \\
0.944\end{array}$ & $\begin{array}{l}-0.631 \\
0.002\end{array}$ & $\begin{array}{l}-0.553 \\
0.002\end{array}$ & $\begin{array}{l}0.570 \\
0.001\end{array}$ & $\begin{array}{l}-0.020 \\
0.915\end{array}$ & $\begin{array}{l}0.062 \\
0.747\end{array}$ \\
\hline Chol & & & & & & & & & $\begin{array}{l}1.000 \\
0.000\end{array}$ & $\begin{array}{l}0.59 \\
0.001\end{array}$ & $\begin{array}{l}0.529 \\
0.003\end{array}$ & $\begin{array}{l}-0.934 \\
0.001\end{array}$ & $\begin{array}{l}-0.548 \\
0.002\end{array}$ & $\begin{array}{l}-0.321 \\
0.082\end{array}$ & $\begin{array}{l}0.754 \\
0.001\end{array}$ & $\begin{array}{l}0.753 \\
0.001\end{array}$ \\
\hline LDL & & & & & & & & & & $\begin{array}{l}1.00 \\
0.000\end{array}$ & $\begin{array}{l}-0.095 \\
0.619\end{array}$ & $\begin{array}{l}-0.056 \\
0.768\end{array}$ & $\begin{array}{l}0.172 \\
0.364\end{array}$ & $\begin{array}{l}-0.024 \\
0.90\end{array}$ & $\begin{array}{l}0.181 \\
0.337\end{array}$ & $\begin{array}{l}0.400 \\
0.028\end{array}$ \\
\hline $\mathrm{HDL}$ & & & & & & & & & & & $\begin{array}{l}1.000 \\
0.000\end{array}$ & $\begin{array}{l}0.032 \\
0.869\end{array}$ & $\begin{array}{l}-0.170 \\
0.371\end{array}$ & $\begin{array}{l}-0.115 \\
0.544\end{array}$ & $\begin{array}{l}0.579 \\
0.001\end{array}$ & $\begin{array}{l}0.592 \\
0.001\end{array}$ \\
\hline Athl & & & & & & & & & & & & $\begin{array}{l}1.000 \\
0.000\end{array}$ & $\begin{array}{l}0.591 \\
0.006\end{array}$ & $\begin{array}{l}-0.882 \\
0.0001\end{array}$ & $\begin{array}{l}0.508 \\
0.004\end{array}$ & $\begin{array}{l}0.356 \\
0.054\end{array}$ \\
\hline Thrl & & & & & & & & & & & & & $\begin{array}{l}1.000 \\
0.000\end{array}$ & $\begin{array}{l}-0.415 \\
0.022\end{array}$ & $\begin{array}{l}0.113 \\
0.551\end{array}$ & $\begin{array}{l}0.156 \\
0.409\end{array}$ \\
\hline Hypochl & & & & & & & & & & & & & & $\begin{array}{l}1.00 \\
0.00\end{array}$ & $\begin{array}{l}-0.426 \\
0.02\end{array}$ & $\begin{array}{l}-0.278 \\
0.136\end{array}$ \\
\hline TAC & & & & & & & & & & & & & & & $\begin{array}{l}1.000 \\
0.000\end{array}$ & $\begin{array}{l}0.754 \\
0.001\end{array}$ \\
\hline MDA & & & & & & & & & & & & & & & & $\begin{array}{l}1.000 \\
0.000\end{array}$ \\
\hline
\end{tabular}

SFA saturated fatty acids, UFA unsaturated fatty acids, PUFA poly unsaturated fatty acids, MUFA monounsaturated fatty acids, Omg3 omega 3 fatty acid, Omg6 omega 6 fatty acid, Omg7 omega 7 fatty acid, Omg9 omega 9 fatty acid, LDL low density lipoprotein, HDL high density lipoprotein, Athl atherogenic index, Thrl thrombotic index, Hypochl hypocholesterolemic index

magnitude. On the other hand, the correlations between UFA, cholesterol and MDA were significantly negative with a low magnitude; the correlation between UFA and total antioxidant capacity (TAC) was negative to a moderate power, and the correlation between UFA and the atherogenic and thrombogenic indices was significantly negative with a high magnitude.

The relationship between MUFA and omega-7 and omega- 9 was significantly positive with a perfect magnitude, while the correlation between MUFA and the atherogenic, thrombotic and hypocholesterolemic indices was significantly positive with a moderate power.

The correlation between PUFA and omega- 6 was significantly positive to a perfect power, while the relationship between PUFA, omega-3 and the hypocholesterolemic index was significantly positive to a moderate magnitude. In addition, the correlation between PUFA and total cholesterol, the atherogenic index, TAC and MDA was significantly negative to a moderate magnitude.

The relationship between omega- 3 and omega- 6 and the thrombotic and hypocholesterolemic indices was significantly positive to a moderate power, but negative to a moderate power with TAC.

The correlation between omega- 6 and total cholesterol, the atherogenic index, TAC and MDA was negative to a moderate power, but was positive to a moderate magnitude with the hypocholesterolemic index.

The correlation between omega- 9 with omega-7 and the hypocholesterolemic index was significantly positive to perfect and low powers, respectively, but the relationship with the atherogenic index and the thrombotic index was negative with a moderate magnitude.

The relationship between omega-7 and the hypocholesterolemic index was significantly positive with moderate 
power, while the correlation with the atherogenic index and the thrombogenic index was negative to a moderate magnitude.

There was a significant positive correlation between total cholesterol and LDL- and HDL- cholesterol with a moderate magnitude, while the relationship between total cholesterol and TAC and MDA was positive to a high magnitude. In addition, the correlation between total cholesterol with the atherogenic and thrombogenic indices was significantly negative with perfect and moderate magnitudes, respectively.

LDL cholesterol correlated positively with MDA, but the power of the correlation was moderate, while HDL cholesterol showed a positive significant correlation with a moderate magnitude with TAC and MAD. The atherogenic index exhibited a significant positive moderate relationship with the thrombotic index and with TAC, but the relationship was significantly negative with a high power with the hypocholesterolemic index. The thrombotic index showed a significant negative moderate relationship with the hypocholesterolemic index. The relationship between TAC and MDA was significantly positive with a strong power.

\section{Discussion}

In the literature, the relationship between type of food consumed and particularly dietary fats, antioxidants and health status are well documented [4, 25-28]. Epidemiological studies conducted worldwide, supported the association between poultry meat consumption, within a balanced diet, and a reduction in the risk of developing cardiovascular diseases and their risk factors [29] Other study reveals that, the substitution of red meat with poultry could therefore constitute an effective strategy to reduce coronary risk by $19 \%$ [30]. It was observed that differences in the hypocholesterolemic index of meat from broilers from the retail market were found to be affected by the type of meat (frozen vs. fresh). Source D of fresh meat showed the greatest hypocholesterolemic index and the lowest total SFA and MDA, but the highest UFA, UFA/SFA, PUFA and omega-6, which are favourable effects. In the literature, as shown herein, high cholesterol correlates with high SFA content $(r=-0.907 ; P=0.001)$ $[4,15,31,32]$. Further evidence supported our hypothesis that broiler meat quality in the retail market has different nutritional values, and hence we can assume different human health impacts. This can be seen in differences in the atherogenic index and in the omega- 6 fatty acids. Hence the favourable hypocholesterolemic, atherogenic and thrombogenic indices, and the favourable TAC and MDA, were from the fresh meat, indicating that freezing the meat had a negative impact on its quality. These differences can primarily be attributed to diet composition, i.e. to the consumption of the feeds offered to the animals
[13, 19, 33]. This indicates that consumers can benefit their health by being selective with broiler meat, not only for improving their PUFA fatty acid intake, but also for reducing their hypocholesterolemic, atherogenic and thromboitic indices. The freezing technique can affect the carcasses and the meat quality, as the freezing process can affect the water fraction of the meat [34]. With the freezing of water, the concentration of the remaining solutes (proteins, carbohydrates, lipids, vitamins and minerals) increases, thereby upsetting the homeostasis of the complex meat system [35]. The changes in the immediate environment of the muscle fibres affect the cell membrane characteristics. That, in turn, affects the quality of the meat [35]. Consumers' preference for leaner carcasses has also increased in recent years [36].

The quality of poultry meat is affected by many factors, such as dietary nutrient intake. The most biological aspects are genotype, sex and age [2, 27, 33, 37]. Another factor that can influence poultry meat quality and compositional changes in the meat is the rearing system for broilers [2, 38-40]. Hence, increasing intakes of SFA, cholesterol, and the atherogenic and thrombogenic indices have negative health implications [2, 4, 33]. These substances have been connected with higher cardiovascular threats and with thrombosis associated with increasing levels of blood cholesterol [28, 29, 33, 41, 42]. In this regard, the hypocholesterolemic index was found to be significantly correlated with the thrombogenic index and with TAC. This indicates a need for standardization of nutrition in terms of the fatty acid contents of diets and in husbandry practices to minimise variation and improve quality of chickens' meat.

The lack of significant differences between TAC and MDA (the biomarker for lipid peroxidation) among the different meat types and sources indicates that the intake of antioxidants such as vitamin $\mathrm{E}$, vitamin $\mathrm{C}$, carotenoids and Se was adequate for postharvest preservation. Antioxidants are usually supplemented at sufficient amounts, considering the recent trend in animal nutrition for improving the shelf life of animal products [2, 25, 26], of animal fatty acid profiles and of immunity [2, 33, 43].

Meat fatty acids profiles, SFA, UFA, MUFA, PUFA, omega-3, omega-6, omega-7 and omega- 9 , and the ratios among them, showed a significant effect of the type or source of meat that can be attributed to dietary composition and feed consumption. In general, source D of fresh meat showed the best profile, showing the lowest SFA, with the highest UFA, UFA/SFA, PUFA, omega-3 and omega- 6 PUFA while the worst profile was from source $\mathrm{E}$ of fresh meat.

The D source of fresh meat was the richest source of linoleic and of eicosapentaenoic acid (EPA). EPA has been reported as a fatty acid that is beneficial for reductions in total mortality, cardiovascular mortality, morbidity, 
atherosclerosis [44], for obstructing the propagation of breast and prostate cancer cell lines in vitro, and for reducing the risk and development of these tumours in animal experiments [45]. It should be mentioned that the conversion of $\alpha$-linolenic acid by the body to the more active longer-chain metabolites is inefficient, being $5-10 \%$ for EPA and 2-5\% for DHA [46]. A common feature of most of the proposed mechanisms by which fatty acids might lower cancer risk is the inhibition of eicosanoid production from (n-6) fatty acid precursors [47], which include linoleic acid, found primarily in vegetable oils, and arachidonic acid, found primly in animal products.

Source A of frozen meat showed a fatty acid profile similar to that of source D of fresh meat, with different patterns for only the oleic and linoleic fatty acids. This indicates that the dietary fatty acid composition and their consumption by the chickens were different. Differences in fatty acid contents in animal products have been found to be affected by lipid metabolism and fats/ fatty acids composition [12, 14, 18, 19, 48]. This agrees with the present results. However, there are also several other factors of a secondary order that can affect the lipid and cholesterol contents of meat, such as feed additive supplementation $[13,25,27,43]$, the age, sex and strain of the broilers [49], flock husbandry, the season, the length of the rearing period [50-52], and the cooking and storage conditions [21,53].

Correlation analyses can draw the type and strength of the relationships among the different variables under investigation. SFA showed a significant strong negative relationship with the hypocholesterolemic index, but a moderate positive relationship with TAC, as SFA is less susceptible to lipid peroxidation. The correlation between UFA and the hypocholesterolemic index was significantly positive, while the relationship with the atherogenic and thrombotic indices was strongly negative. This can be attributed particularly to PUFA. PUFA exhibited a significantly positive relationship of a moderate magnitude with the hypocholesterolemic index and a significantly negative relationship of a moderate magnitude with total cholesterol, the atherogenic index, TAC and MDA. Thus meat enhanced with PUFA can have a beneficial health benefit for humans, as recently recommended and as shown by increasing consumer preferences $[12,18,19]$.

The relationship between omega- 3 and the thrombotic index and the hypocholesterolemic index was significantly positive with a moderate degree of power. In addition, omega- 6 and total cholesterol, the atherogenic index, TAC and MDA showed negative correlations with moderate power, but positive relationships of a moderate magnitude with the hypocholesterolemic index. Thus omega- 6 and omega- 3 and their ratio (omega-6/ omega-3) are the principle fatty acids controlling the hypocholesterolemic index, and thus should be given the highest priority in broiler feeding programs due to their positive health implications for human [12, 19, 47]. Omega-3 plays a major role in regulating the thrombotic index, while omega- 6 is dominant in the atherogenic index, TAC and MDA [4]. The negative impact of omega6 on TAC and MDA can be attributed to their high susceptibility to lipid peroxidation and thus low antioxidant status in animal products. Hence antioxidant supplementation is essential for diets containing increasing amounts of PUFA in animal products $[13,43]$. A healthy animal product can be characterized by low hypercholesterolemic, atherogenic and thrombogenic indices [4, 33, 42].

Myristic and palmitic acids are among the most atherogenic agents, whereas stearic is thought to be neutral with respect to atherogenicity but is instead considered to be thrombogenic [33, 42]. Poultry meat with high UFA content is preferable for customers due to its low cholesterol (hypocholesterolemic index), LDL/HDL and lower atherogenic index [29, 30, 53]. In literature, feeding an atherogenic diet exhibited marked elevation in total serum cholesterol (hypercholesterolemic), LDL, VLDL, and triglyceride levels, along with decreased HDL levels [54]. Hence low atherogenic, thrombogenic and hypercholesterolemic foods are good for retarding atherosclerosis and thus the risk of cardiovascular disorders in human [4, 27, 28, 42]. Furthermore, animal products with low thrombogenicity decrease the threat of atrial fibrillation [55]. It should be mentioned that consumption of $300 \mathrm{~g}$ of broiler meat resulted in $216 \mathrm{mg}$ of cholesterol, which represented (72\%) of the recommended $300 \mathrm{mg}$ daily allowance of cholesterol for adults [56].

\section{Conclusions}

Fatty acids profiles and the hypocholesterolemic and atherogenic indices of broiler meat in the retail market in Jeddah city, Saudi Arabia during April, May and June 2014 showed significant differences, with the potential for favourable fatty acids to be boosted. Such variability indicates the needs for a feeding strategy to enhance the favourable fatty acids that may positively impact the health of the consumer, lowering the risk of hypercholesterolemia, atherosclerosis, and thrombogenesis although further studies are needed.

\section{Methods \\ Materials}

Ninety whole carcasses of chickens were randomly collected during April-May-June 2014 from 6 sources, named A, B, C, D, E and F, chosen randomly from a retail store. The samples represented two types of chicken carcasses, imported frozen carcasses (A, B and C) from Brazil and France, and locally produced fresh carcasses (D, E, and F), in the Hyper Panda retail market, in Jeddah, Saudi Arabia. 
Meat samples were 5-pooled samples/source/time, which were replicated 3 times, resulting in a total of 15 samples/ source of each meat type. The carcasses were chosen from grade A of each source and were of similar carcass weight $(1 \mathrm{~kg})$. The chicken carcasses had similar dates of production and expiration when collected from the retail markets. The carcasses were cut into two halves. The right side of the carcasses was skinned and deboned, and the meat was minced using a meat mincer (Moulinex-HV8, France). The meat samples were pooled over time to represents 5 samples/source/type, and were immediately frozen at $-20^{\circ} \mathrm{C}$ until further analysed.

The chickens were reared under commercial operating conditions and were managed using common husbandry practice for broiler chickens, but the details of rearing and husbandry practices and the feeding regimens were not provided by the producing companies. The chickens were slaughtered in an automatic slaughterhouse according to the Islamic method.

\section{Measurements \\ Cholesterol profiles, total antioxidants capacity and malondialdehyde}

Lipids were extracted according to [57] to determine meat cholesterol [58], high-density lipoprotein (HDL) [59] and low-density lipoprotein (LDL) [60]. Total antioxidant capacity (mmoles $\backslash 100 \mathrm{~g}$ fresh weight) and lipid peroxidation biomarkers, such as malonyldialdehyde (mmoles $\backslash g$ fresh weight), were determined according to [61, 62], respectively. The determinations were done using commercial kits (Diamond Diagnostics, 33 Fiske St, Holliston MA 01746, USA).

\section{Fatty acids profiles of the meat lipids}

A part of the lipids extracted from the meat was used for the determination of fatty acid profiles of the meat by Shimadzu Gas Chromatograph GC-4CM (PFE) connected to a glass column ( $3 \mathrm{X} 3 \mathrm{~mm}$ i.d.) packed with $5 \%$ diethylene glycol succinate (DEGS) and detector of flame ionization (FID). The separation and identification was as follows: Column temperature $1800 \mathrm{C}$; temperature for both injector and detector were $2700 \mathrm{C}$; nitrogen, hydrogen and air were used as a carrier gas at flow rates $(\mathrm{ml} / \mathrm{min}$.) of 30 , 1 and 0.5 , respectively, according to [63]. A standard of fatty acid methyl esters was treated under the same conditions before analysis of the samples. The fatty acids of the sample were identified by comparison of their retention times (tR) with the standard. The sample size was 5pooled samples over 3 times per each meat source of each type of meat. Atherogenic and thrombogenic indexes were calculated according to [64]. The hypocholesterolemic index was calculated according to [65].

\section{Statistical analyses}

Data were statistically analysed according to [66] using the PROC NESTED procedures according the following model:

$$
\mathrm{Y}_{\mathrm{ijk}}=\mu+\mathrm{C}_{\mathrm{i}}+\mathrm{B}_{\mathrm{ij}}+\mathrm{e}_{\mathrm{ijk}}
$$

$\mathrm{Y}_{\mathrm{ijk}}=$ observed value of the dependent variable; $\mu$ : overall mean; Ci: effect of meat type (frozen vs. fresh); Bij: effect of type within source; eijklm: experimental error of random distribution $(0, \sigma 2)$.

Before running the statistical analyses, all percentages were transformed to arc sins to normalize data distribution. Significance of differences was tested at $(P<0.05)$ for all means according to [67].

\section{Acknowledgments}

This work was funded by the Deanship of Scientific Research (DSR) at King Abdulaziz University, Jeddah. The authors, therefore, acknowledge with thanks DSR for technical and financial support.

\section{Funding}

This research was supported by the Deanship of Scientific Research (DSR) at King Abdulaziz University, Jeddah, Saudi Arabia.

\section{Availability of data and materials}

The published, the software application/tool were readily available to any scientist wishing to use it for non-commercial purposes, without restrictions.

\section{Authors' contributions}

YAA performed experiments, conception and design of research, analysed data, interpreted results of experiments, edited and revised manuscript; MAA: performed experiments, conception and design of research, analysed data, interpreted results of experiments, edited and revised manuscript; MAK: performed experiments, interpreted results of experiments, approved final version of manuscript; MMS: performed experiments, drafted manuscript. All authors read and approved the final manuscript.

\section{Competing of interest}

The authors declare that they have no competing interests.

\section{Consent for publication}

The data will not be shared as it is a part of DSR-KAU funded project that is in progress. The funding agent hold the right.

\section{Ethics approval and consent to participate}

The experimental protocol of this study was approved at 1/1/1435 by Deanship of Scientific Research, King Abdulaziz University, under distinguish study no 155-313-D1435. The work did not include any human or animal subjects.

\section{Author details}

${ }^{1}$ Arid Land Agriculture Department, Faculty of Meteorology, Environment and Arid Land Agriculture, King Abdulaziz University, P.O. Box 80208, Jeddah

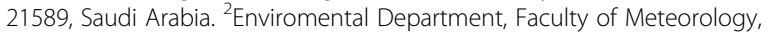
Environment and Arid Land Agriculture, King Abdulaziz University, P.O. Box 80208, Jeddah 21589, Saudi Arabia. ${ }^{3}$ Department of Food and Dairy Science \&Technology, Faculty of Agriculture, Damanhour University, Damanhour 22516, Egypt.

Received: 29 February 2016 Accepted: 24 January 2017

Published online: 16 February 2017

\section{References}

1. World Health Organization (WHO). Protein and amino acid requirements in human nutrition. Report of a joint FAO/WHO/UNU expert consultation (WHO Technical Report Series 935) 24 March 2007. 
2. Bogosavljevi-Boškovi S, Pavlovski Z, Petrovi MD, Doskovi V, Rakonjac S. Broiler meat quality: Proteins and lipids of muscle tissue. Afr J Biotechnol. 2010;9(54):9177-82.

3. Hellmeister F, Machadomenten JF, Neves Da Silva MA, Coelho AAD, Savino VJM. Efeito de Genótipo e do Sistema de Criacâo sobre o Desempenho de frangos Tipo Caipira. R Bras Zootec. 2003;32(6):1883-9.

4. Kratz M. Dietary cholesterol, atherosclerosis and coronary heart disease. Handb Exp Pharmacol. 2005;170:195-213.

5. Keys A. Seven Countries: A multivariate analysis of death and coronary heart disease. Cambridge: Harvard University Press; 1980.

6. Mensink RP, Katan MB. Effect of dietary fatty acids on serum lipids and lipoproteins: a meta-analysis of 27 trials. Arterioscler Thromb. 1992;12:911-9.

7. Hibbeln JR, Nieminen LR, Blasbalg TL, Riggs JA, Lands WE. Healthy intakes of $n-3$ and $n-6$ fatty acids: estimations considering worldwide diversity. Am J Clin Nutr. 2006:83:1483S-93S.

8. Ian Givens D, Gibbs RA. Current intakes of EPA and DHA in European populations and the potential of animal-derived foods to increase them. Proc Nutr Soc. 2008;67:273-80.

9. Fraser GE. Diet and coronary heart disease: beyond dietary fats and lowdensitylipoprotein cholesterol. Am J Clin Nutr. 1994;59(suppl):117-1123.

10. Hu FB, Stampfer MJ, Manson JE, Ascherio A, Colditz GA, Speizer FE, et al. Dietary saturated fats and their food sources in relation to the risk of coronary heart disease in women. Am J Clin Nutr. 1999:70:1001-8.

11. Grashorn MA, Clostermann G. Mast- und Schlachtleistung von Broilerherkünften für die Extensivmast. Arch Geflügelk. 2002;66(4):173-81.

12. Wood JD, Richardson RI, Nute GR, Fisher AV, Campo MM, Kasapidou E, et al. Effects of fatty acids on meat quality: a review. Meat Sci. 2003;66(1):21-32.

13. Andersen HJ, Oksbjerg N, Young JF, Therkildsen M. Review. Feeding and meat quality - a future approach. Meat Sci. 2005;70:543-54.

14. FAOMHO. Expert Consultation on fats and fatty acids in human nutrition. Geneva; 2008. http://eproofing.springer.com/journals/mainpage.php?token= MdKejAjkgGCrnHFOFQ0Z5ELPQTkXJmSycfiEEEMsYaU\#.

15. Laudadio V, Ceci E, Edmondo M B, Lastella N, Tufarelli V. Dietary highpolyphenols extra-virgin olive oil is effective in reducing cholesterol content in eggs. Lipids Health Dis. 2015;14(5). doi:10.1186/s12944-015-0001-x. (In Press)

16. Elisabeth LB-D, Martine D, Berri Cécile M, Sellier N, Santé-Lhoutellier V, Jégo Y, Beaumont C. Chicken meat quality: genetic variability and relationship with growth and muscle characteristics. BMC Genet. 2008;9:53. http:// bmcgenet.biomedcentral.com/articles/10.1186/1471-2156-9-53.

17. Tang H, Gong YZ, Wu CX, Jiang J, Wang Y, Li K. Variation of meat quality traits among five genotypes of chicken. Poultry Sci. 2009;88:2212-8.

18. Bonoli M, Caboni MF, Rodriguez-Estrada MT, Lercker G. Effect of feeding fat sources on the quality and composition of lipids of precooked ready-to-eat fried chicken patties. Food Chem. 2007;101:1327-37.

19. Grashorn MA. Functionality of poultry meat. J Appl Poult Res. 2007;16:99-106.

20. Castellini C, Mugnai C, Dal BA. Effect of organic production system on broiler carcass and meat quality. Meat Sci. 2002;60:219-25.

21. Conchillo A, Ansorena D, Astiasara'N I. The effect of cooking and storage on the fatty acid profile of chicken breast. Eur J Lipid Sci Tech. 2004;106:301-6.

22. Fanatico AC, Pillai PB, Emmert JL, Owens CM. Meat quality of slow- and fastgrowing chicken genotypes fed low-nutrient or standard diets and raised indoors or with outdoor access. Poultry Sci. 2007;86:2245-55.

23. Javanmard M, Rokni N, Bokaie S, Shahhosseini G. Effects of gamma irradiation and frozen storage on microbial, chemical and sensory quality of chicken meat in Iran. Food Control. 2006;17:469-73.

24. Bianchi M, Petracci M, Sirri F, Folegatti E, Franchini A, Meluzzi A. The influence of the season and market class of broiler chickens on breast meat quality traits. Poultry Sci. 2007;86:959-63.

25. Attia YA, Abdalah AA, Zeweil HS, Bovera F, Tag El-Din AA. Araft M A. Effect of inorganic or organic selenium supplementation on productive performance egg quality and some physiological traits of dual purpose breeding hens. Gech J Anim Sci. 2010:55:505-19.

26. Attia YA, Al-Harthi MA, Shiboob MM. Evaluation of quality and nutrient contents of table eggs from different sources in the retail market. Ital J Anim Sci. 2014;13:369-76.

27. Rozbicka-Wieczorek AJ, Wiesyk E, Brzoska F, Sliwinski B, Kowalczyk J, Czauderna M. Efficiency of fatty acids accumulation into breast muscles of chickens fed diets with lycopene, fish oil and different chemical selenium forms. Afr J Biotech. 2014;13:1604-13.

28. Kliševičiūtè $V$, Gružauskas R, Racevičiūtè-Stupelienè A, Daukšienè A Švirmickas GJ, Mieželienè A, Alenčikienè G. Influence of different amount of whole triticale on productivity and meat quality of broiler chickens. Veterinarija Ir Zootechnika (Vet Med Zoot) T. 2014;66:88.

29. Franca M, Corsello G, Cricelli C, Ferrara N, Ghiselli A, Lucchin L, Poli A. Role of poultry meat in a balanced diet aimed at maintaining health and wellbeing: an Italian consensus document. Food Nutr Res. 2015;59:27606. http://www. tandfonline.com/doi/full/10.3402/fnr.v59.27606.

30. Hu FB. Protein, body weight, and cardiovascular health. Am J Clin Nutr. 2005;82(1 Suppl):242S-7S.

31. Van Dyck MO, Adams AC. Dietary antioxidants- antiradical active nutricines. Int J Poultry Sci. 2003;11:15-9.

32. Wijendran V, Hayes KC. Dietary $n-6$ and $n-3$ fatty acid balance and cardiovascular health. Annu Rev Nutr. 2004;24:597-615.

33. Vitina II, Cerina S, Jansons J, Karstina V, Daugavietis M, Polis O, Korica A, Anenkova R, Lujane B. Functional Poultry meat enriched with biologically active substances from neutral extractives obtained from Spruce Needles. Krmiua. 2012;5:151-8.

34. Adzitey F. Effect of pre-slaughter animal handling on carcass \& meat quality. Int Food Res J. 2011;18:484-90.

35. Akhtar S, Khan Ml, Faiz F. Effect of Thawing on Frozen Meat Quality: A comprehensive Review. Pak J Food Sci. 2013;23:198-211.

36. Fellows P. Food Processing Technology : Principles and Practice. 2 nd ed. Chichester: Ellis Horwood; 2000

37. Tumova E, Teimouri A. Fat deposition in the broiler chicken: a review. Sci Agric Bohem. 2010;41:121-8.

38. Ristic M. Influence of breed and weight class on the carcass value of broilers. In: Xllth European Symposium Quality of Poultry Meat, Doorwerth, The Netherlands; 2005

39. Antonija H, Vadnjal R, Žledner B, Vekoslava S. Chemical composition of chicken meat from free range and extensive indoor rearing. Arch Geflügelk. 2003:67(3):120-4.

40. Snezana B-B, Zlatica P, Petrovic DM, Doskovic V, Rakonjac S. The effect of rearing system and length of fattening period on selected parameters of broiler meat quality. Archiv für Geflügelk. 2011;75.

41. Weggemans RM, Zock PL, Katan MB. Dietary cholesterol from eggs increases the ratio of total cholesterol to high-density lipoprotein cholesterol in humans: A meta-analysis. Am J Clin Nutr. 2001;73:885-91.

42. Laudadio V, Tufarelli V. Growth performance and carcass and meat quality of broiler chickens fed diets containing micronized-dehulled peas (Pisum sativum cv. Spirale) as a substitute of soybean meal. Poult Sci. 2010;89:1537-43.

43. Surai PF. Reviews: Selenium in poultry nutrition 2. Reproduction, egg and meat quality and practical applications. World Poultry Sci J. 2002;58:431-50.

44. von Schacky $C$. The role of omega-3 fatty acids in cardiovascular disease. Curr Atheroscler Rep. 2003;5:139-45.

45. Terry PD, Terry J, Roha TE. Long-Chain (n-3) Fatty acid intake and risk of cancers of the breast and the prostate: recent epidemiological studies, biological mechanisms, and directions for future research. J Nutr. 2004;134:3412-20.

46. Davis BC, Kris-Etherton PM. Achieving optimal essential fatty acid status in vegetarians: current knowledge and practical implications. Am J Clin Nutr. 2003;78:640-6.

47. Rose DP, Connolly JM. Omega-3 fatty acids as cancer chemopreventive agents. Pharmacol Ther. 1999;83:217-44.

48. Groom GM. Factors affecting poultry meat quality. In: Sauveur B. (Ed.). L'aviculture en Méditerranée. Montpellier: CIHEAM; 1990. p. 205-10. Options Méditerranéennes : Série A. Séminaires Méditerranéens; $n$. 7.

49. Abeni F, Bergoglio G. Characterization of different strains of broiler chicken by carcass measurement, chemical and physical parameters and NIRS on breast muscle. Meat Sci. 2001;57:133-7.

50. Bogosavljevic-Boskovic S, Gajic l; Gajic Z. The influence of rearing systems on basic tissue share and muscle chemical structure in broilers. 45th International Congress of Meat Science and Technology, 01-06. August, Yokohama, Japan, Proceedings; 1999. p.510-11.

51. Snezana B-B, Kurcubic V, Petrovic DM, Radovic $V$. The effect of sex and rearing system on carcass composition and cut yields of broiler chickens. Czech J Anim Sci. 2006:51(1):31-8.

52. Snezana B-B, Kurcubic V, Petrovic M, Doskovic $V$. The effect of season and rearing system on meat quality traits. Czech J Anim Sci. 2006:51(8):369-74.

53. Al-Najdawi R, Abdullah B. Proximate composition, selected minerals, cholestero content and lipid oxidation of mechanically and hand-deboned chickens from the Jordanian market. Meat Sci. 2002;61:243-7.

54. El-Wakf AM, Ebraheem HA, Serag HA, Hassan HA, Gumaih HS. Association between inflammation and the risk of cardiovascular disorders in 
atherogenic male rats: Role of virgin and refined olive oil. J Am Sci. 2010; 6(12):807-17.

55. Watson T, Eduard S, Lip GYH. Mechanisms of thrombogenesis in atrial fibrillation: Virchow's triad revisited. Lancet. 2009;373(9658):155-66.

56. Dietary Reference Intakes for Energy, Carbohydrate, Fiber, Fat, Fatty Acids Cholesterol, Protein and Amino Acids RDA 2002/2005. Office of dietary supplements -National Institute of health. USA. Gov.www.nap.edu, assayed 20 Oct 2012.

57. Folch J, Lees M, Stanley G. A simple method for isolation and purification of total lipids from animal tissues. J Biochem Chem. 1957;226:497-509.

58. Allain CC, Poon LS, Cicely S, Chan G, Richmond W, Fu PC. Enzymatic determination of total serum cholesterol. Amer Assoc of Clin Chem. 1974;20:470-5.

59. Lopez-Virella MF, Stone P, Ellis S, Colwell JA. Cholesterol determination in high-density lipoproteins separated by three different methods. Clin Chem. 1977;23:882-4

60. Wieland H, Seidel D. A simple specific method for precipitation of low density lipoproteins. J Lipid Res. 1983;24:904-9.

61. Koracevic D, Koracevic G, Djordjevic V, Andrejevic S, Cosic V. Method for the measurement of antioxidant activity in human fluids. J Clin Path. 2001;54:356-61.

62. Ohkawa H, Ohishi N, Yagi K. Assay for lipid peroxides in animal tissues by thiobarbituric acid reaction. Anal Biochem. 1979:95:351-8.

63. Radwan SS. Coupling of two-dimension thin layer chromatography with gas chromatography for the quantitative analysis of lipids classes and their constituent fatty acids. J Chromatog Sci. 1978;16:538-42.

64. Ulbricht TL, Southgate DAT. Coronary heart disease: Seven dietary factors. Lancet. 1991;338:985-92.

65. Fernández M, Ordóñez JA, Cambero I, Santos C, Pin C, De la Hoz L. Fatty acid compositions of selected varieties of Spanish dry ham related to their nutritional implications. Food Chem. 2007;9:107-12.

66. SAS, Institute 2009. User's guide. Version 9.2 2nd ed. SAS institute Inc. Cary NC. USA.

67. Steel RGD, Torrie JH. Principles and procedures of statistics. 2nd ed. New York: McGraw-Hill; 1980.

\section{Submit your next manuscript to BioMed Central and we will help you at every step:}

- We accept pre-submission inquiries

- Our selector tool helps you to find the most relevant journal

- We provide round the clock customer support

- Convenient online submission

- Thorough peer review

- Inclusion in PubMed and all major indexing services

- Maximum visibility for your research

Submit your manuscript at www.biomedcentral.com/submit

) Biomed Central 